$\begin{array}{lrrrrrrr}\text { Volume } & 13, \quad \text { Nomor } & 1, & \text { Mei } & \text { 2021, } & \text { pp } 12-22 & \text { Copyright } & \text { C } 2017 \\ \text { Jurnal } & \text { Akuntansi, } & \text { Program } & \text { Studi } & \text { Akuntansi, } & \text { Fakultas } & \text { Bisnis, } \\ \text { Universitas } & \text { Kristen } & \text { Maranatha. } & \text { ISSN } & 2085-8698 & \text { e-ISSN } & 2598-4977 .\end{array}$

http://journal.maranatha.edu

\title{
Pandemi COVID-19 dan Prediksi Kebangkrutan: Apakah Kondisi Keuangan Sebelum 2020 Berperan?
}

\author{
Mikhael Andre Kurniawan ${ }^{1}$ \\ Universitas Kristen Satya Wacana \\ (Jl. Diponegoro No. 52-60, Salatiga, Jawa tengah) \\ 232017504@student.uksw.edu \\ Kerinea Estetika Hariadi ${ }^{2}$ \\ Universitas Kristen Satya Wacana \\ (Jl. Diponegoro No. 52-60, Salatiga, Jawa tengah) \\ 232017513@student.uksw.edu \\ Widya Oktarina Sulistyaningrum ${ }^{3}$ \\ Universitas Kristen Satya Wacana \\ (Jl. Diponegoro No. 52-60, Salatiga, Jawa tengah) \\ 232017085@student.uksw.edu \\ Ari Budi Kristanto 4 \\ Universitas Kristen Satya Wacana \\ (J1. Diponegoro No. 52-60, Salatiga, Jawa tengah) \\ ari.kristanto@uksw.edu
}

\begin{abstract}
This study aims to analyze the impact of the COVID-19 pandemic on the prediction of company bankruptcy in Indonesia, with financial conditions before 2020 (cash position and debt position) as moderating variables. Relationship between variables was tested using a logistic regression analysis model test with a moderation model. The population in this study are manufacturing companies listed on the Indonesia Stock Exchange. A total of 169 samples were obtained using purposive sampling with the criteria: listed on the IDX in 2020, had financial information for 2019-2020, and the company reported information disclosure regarding the impact of the pandemic. The results show that companies with a high impact of the COVID-19 pandemic will be more predicted to go bankrupt, furthermore the cash position and debt ratio in 2019 have no moderating effect.
\end{abstract}

Keywords: Bankruptcy, Liquidity, Leverage, Pandemic COVID-19 


\begin{abstract}
Abstrak
Penelitian ini bertujuan untuk menganalisis dampak pandemi COVID-19 terhadap prediksi kebangkrutan perusahaan di Indonesia, dengan kondisi keuangan sebelum 2020 (posisi kas dan posisi hutang) sebagai variabel pemoderasi. Hubungan antar variabel diuji menggunakan uji model analisis regresi logistik dengan model moderasi. Populasi dalam penelitian ini adalah perusahaan manufaktur yang terdaftar di Bursa Efek Indonesia. Sebanyak 169 sampel diperoleh dengan menggunakan purposive sampling dengan kriteria: terdaftar dalam BEI di tahun 2020, memiliki informasi keuangan tahun 2019-2020, dan perusahaan tersebut melaporkan keterbukaan informasi terkait dampak pandemi. Hasil penelitian menunjukkan bahwa perusahaan dengan dampak pandemi COVID-19 yang tinggi akan lebih diprediksi untuk bangkrut, sedangkan posisi kas dan rasio hutang pada tahun 2019 tidak mampu menjadi variabel moderasi.
\end{abstract}

\title{
Kata Kunci: Kebangkrutan, Likuditas, Leverage, Pandemi COVID-19
}

\section{Pendahuluan}

Pandemi COVID-19 yang mengakibatkan krisis kesehatan dunia memaksa pemerintah menetapkan beberapa kebijakan untuk membatasi pergerakan masyarakat (Silalahi \& Ginting, 2020). Hal tersebut membuat sebagian perusahaan mewajibkan karyawan untuk bekerja dari rumah sehingga menyebabkan kegiatan operasional perusahaan menjadi terganggu (Nurmasari, 2020). Terganggunya aktivitas operasional perusahaan dapat mempengaruhi kondisi serta performa perusahaan. Dampak pandemi COVID-19 ini mengakibatkan hanya $58,95 \%$ perusahaan mampu beroperasi secara normal, bahkan sebanyak $82,45 \%$ perusahaan mengalami penurunan pendapatan (Badan Pusat Statistik, 2020). Dalam kondisi penurunan pendapatan, korporasi dapat saja masih harus menanggung biaya tetap. Situasi sulit ini dapat meningkatkan risiko kebangkrutan karena perusahaan akan semakin sulit mengupayakan kas untuk memenuhi kewajibannya.

$\begin{array}{ccr}\text { Kondisi } & \text { krisis } & \text { membuat } \\ \text { perusahaan } & \text { kesulitan } & \text { untuk }\end{array}$
mempertahankan kelangsungan usahanya, yang pada akhirnya dapat membawa perusahaan pada kondisi kebangkrutan (Amir \& Sudiyatno, 2017). Kegagalan perusahaan dalam mempertahankan prinsip going concern dapat disebabkan oleh kegagalan ekonomi dan kegagalan keuangan. Terdapat beberapa faktor yang dapat mendorong suatu perusahaan mengalami kebangkrutan antara lain faktor umum, faktor internal, dan faktor eksternal (Tambunan et al., 2015). Suatu perusahaan tentunya berharap untuk dapat mempertahankan kelangsungan usahanya, namun suatu perusahaan juga tidak dapat terhindarkan dari resiko-resiko yang dapat menyebabkan kebangkrutan seperti terlilit hutang (Pangkey et al., 2018). Buruknya manajemen keuangan dan gagalnya suatu perencanaan dapat mengganggu upaya perusahaan dalam mencapai prinsip going concern.

Fakta bahwa pandemi COVID-19 memiliki konsekuensi besar bagi dunia usaha menarik untuk diteliti apakah pandemi COVID-19 sampai membuat perusahaan-perusahaan berisiko mengalami kebangkrutan. Penelitian ini membawa kondisi terkini secara spesifik untuk melihat dampak pandemi COVID-19 yang mungkin dapat berpengaruh pada risiko kebangkrutan. Fokus dampak pandemi COVID-19 terhadap risiko kebangkrutan ini merupakan hal yang baru, mengingat penelitian sebelumnya baru fokus pada dampak pandemi COVID-19 pada posisi 
kas, posisi hutang, dan harga saham (Ding et al., 2020; Qin et al., 2020) Dengan demikian pertanyaan penelitian ini antara lain: (1) Apakah perusahaan yang terdampak pandemi akan terindikasi bangkrut? (2) Apakah kondisi keuangan sebelum 2020 (posisi kas dan posisi hutang) mampu memoderasi pandemi COVID-19 terhadap prediksi kebangkrutan? Penelitian ini menggunakan kondisi keuangan sebelum tahun 2020 (posisi kas dan posisi hutang) sebagai variabel moderasi. Hal ini dikarenakan pada penelitian Wenzhi et al., (2020) menemukan bahwa posisi kas yang lebih tinggi dan posisi hutang yang lebih rendah pada tahun sebelum 2020 dapat meminimalkan dampak pandemi COVID19 terhadap penurunan nilai pasar saham. Secara spesifik penelitian ini akan mengambil objek perusahaan manufaktur yang terdaftar pada Bursa Efek Indonesia (BEI), karena perusahaan pada industri tersebut memiliki karakteristik yang beragam, sehingga diharapkan akan dapat memotret variabilitas dampak pandemi COVID-19. Penelitian ini diharapkan dapat bermanfaat dalam menambah bukti empiris tentang dampak pandemi COVID-19 terhadap perusahaan, sehingga dapat menjadi salah satu acuan pengambilan keputusan baik oleh pemerintah, investor maupun manajemen.

\section{Kerangka Teoretis dan Hipotesis}

\section{Pandemi COVID-19}

Pandemi COVID-19 menyebar begitu cepat yang ditandai dengan tingginya pertambahan kasus masyarakat yang terjangkit di negara Indonesia (Selasi, 2020). Dampak pandemi COVID-19 sangat berpengaruh pada perekonomian global tak terkecuali Indonesia, sehingga perekonomian Indonesia mengalami gangguan pada berbagai sektor (Nurmasari, 2020). Berbagai usaha berskala mikro hingga berskala besar menjadi pihak yang dirugikan oleh dampak pandemi COVID-
19. Hal ini dikarenakan kebijakan pembatasan aktivitas yang ditetapkan pemerintah menyebabkan aktivitas bisnis perusahaan terganggu (Burhanuddin \& Abdi, 2020). Terganggunya aktivitas bisnis suatu perusahaan menyebabkan perusahaan kehilangan pendapatannya dan bahkan terancam tidak mampu untuk menjaga keberlanjutan perusahaan. Berdasarkan keterbukaan informasi yang disampaikan kepada BEI, perusahaan-perusahaan publik di Indonesia antara lain mengalami gangguan operasional, hilangnya pendapatan, karyawan dirumahkan/PHK, risiko gagal bayar hutang, hingga risiko perkara hukum sebagai lanjutan dari gangguan usaha (Bursa Efek Indonesia, 2020).

\section{Prediksi Kebangkrutan}

Kebangkrutan dapat diartikan sebagai kegagalan yang dialami perusahaan dalam menjalankan aktivitas bisnisnnya sehingga perusahaan tidak mampu secara maksimal dalam menghasilkan laba dan bahkan cenderung mengalami defisit (Yami \& Pratiwi, 2015). Kebangkrutan perusahaan diartikan juga sebuah kegagalan perusahaan dalam segi keuangan (financial failure) dan juga segi ekonomi (economic failure) (Ramadhani \& Lukviarman, 2009). Terdapat beberapa faktor internal dan eksternal yang menyebabkan suatu perusahaan mengalami pailit atau bangkrut. Asia \& Irwan (2015) menjelaskan bahwa faktor internal yang menyebabkan kebangkrutan adalah suatu gangguan bagi kinerja perusahaan yang berasal dari bagian manajemen internal perusahaan. Sedangkan faktor eksternal yang mendorong perusahaan tidak mampu mempertahankan performanya adalah hal luar yang dapat berpengaruh secara langsung pada kegiatan operasional perusahaan dan atau faktor yang berasal dari perekonomian makro. Bangkrut merupakan status legal hasil dari keputusan dari suatu proses hukum. Namun dalam literatur penelitian maupun praktek bidang akuntansi dan keuangan, 
kebangkrutan dapat diprediksi menggunakan Altman Z-Score (Tambunan et al., 2015).

\section{Kondisi Keuangan}

Kondisi keuangan adalah suatu komplemen yang digunakan untuk melihat tingkat kesehatan perusahaan melalui laporan keuangan dan sekaligus dapat digunakan untuk memprediksi kebangkrutan perusahaan (Thohari et al., 2015). Posisi kas dan hutang pada laporan keuangan perusahaan akan menjadi informasi penting dalam situasi seperti ini. Likuiditas dapat diartikan sebagai rasio yang memperlihatkan hubungan kas dan aktiva lancar perusahaan dengan kewajiban lancar yang dimiliki perusahan (Arfina, 2013). Apabila perusahaan tidak memiliki kemampuan dalam memenuhi kewajiban lancar maka timbul suatu permasalahan likuiditas yang ekstrim dan berpotensi menyebabkan kebangkrutan. Solvabilitas adalah suatu rasio yang menggambarkan kemampuan perusahaan dalam memenuhi kewajiban jangka panjang (Rompas, 2013).

\section{Pandemi COVID-19 dan Prediksi Kebangkrutan}

Perusahaan akan terdorong cepat mengalami kebangkrutan apabila berada di negara yang sedang mengalami kesulitan dalam pergerakan perekonomiannya (Almilia \& Herdinigtyas, 2005). Perputaran perekonomian Indonesia sedang berada pada kondisi yang terbilang sulit karena adanya kebijakan pemerintah untuk memutus penyebaran pandemi COVID-19 (Silalahi \& Ginting, 2020). Bahkan pertumbuhan perekonomian Indonesia yang awalnya ditargetkan mencapai $5,3 \%$ pada tahun 2020 namun diprediksi hanya mampu mencapai pada angka 2\% saja karena adanya dampak pandemi ini (Hadiwardoyo, 2020). Kesulitan ini dapat mempengaruhi bisnis perusahaan. Disamping itu, kebijakan pembatasan aktivitas masyarakat yang ditetapkan pemerintah juga mengganggu aktivitas bisnis perusahaan sehingga perusahaan tidak mampu menghasilkan laba dengan maksimal hingga berisiko mengalami kebangkrutan.

Hadiwardoyo (2020) menjelaskan bahwa langkah pemerintah dalam menerapkan kebijakan Pembatasan Sosial Berskala Besar (PSBB) menyebabkan adanya kerugian ekonomi yang cukup signifikan bagi berbagai industri dikarenakan perusahaan tidak dapat beroperasi dengan maksimal dalam kurun waktu yang lama. Kerugian besar yang dialami perusahaan karena adanya dampak pandemi COVID-19 ini menyebabkan banyak perusahaan yang mengalami kebangkrutan baik dari perusahaan mikro ataupun makro (Putri et al., 2020).

$\mathbf{H}_{1}$ : Semakin besar dampak pandemi yang dialami, maka perusahaan akan semakin terprediksi bangkrut.

\section{Moderasi Kondisi Keuangan Pra-2020 pada Dampak Pandemi COVID-19 terhadap Prediksi Kebangkrutan}

Kondisi laporan keuangan dapat menjadi informasi yang digunakan untuk pemangku kepentingan dalam menganalisis prediksi kebangkrutan suatu perusahaan (Thohari et al., 2015). Pandemi COVID-19 membawa dampak yang merugikan bagi kondisi arus kas perusahaan dan juga tren pengetatan (penghematan) likuiditas, yang pada akhirnya akan dapat mempengaruhi kinerja perusahaan (Ding et al., 2020). Dalam kondisi seperti ini, perusahaan yang pada tahun sebelumnya memiliki saldo kas yang lebih besar dan rasio leverage yang lebih rendah akan lebih mampu mengantisipasi dampak pandemi COVID-19. Tuntutan pengetatan likuiditas serta tuntutan pembayaran hutang akan membuat terbatasnya saldo kas yang dapat dimanfaatkan untuk aktivitas operasional maupun untuk berjaga-jaga. Sehingga semakin besar tuntutan pengetatan kas dan tuntutan pembayaran hutang terutama dalam kondisi sulit akibat pandemi dapat berdampak buruk seperti tidak dapat dilaksanakannya sebagian aktivitas- 
aktivitas operasi. Dampak dari tuntutan pengetatan likuiditas yang juga dibarengi dengan tuntutan pembayaran hutang akan dapat lebih rendah pada perusahaan yang pada tahun 2019 memiliki saldo kas yang lebih besar. Perusahaan yang memiliki saldo kas tahun 2019 yang lebih besar akan lebih memiliki kelonggaran dalam merespon pengetatan likuiditas, sehingga diharapkan masih cukup tersedia saldo kas untuk aktivitas operasional dan berjagajaga. Demikian pula perusahaan yang pada tahun 2019 menanggung hutang yang lebih kecil (leverage rendah), diharapkan dampak kebutuhan pembayaran hutang di masa pandemi juga akan lebih rendah.

Dewi et al., (2019) menjelaskan bahwa semakin besar tingkat likuiditas yang dimiliki perusahaan maka semakin kecil kemungkinan perusahaan mengalami financial distress atau bangkrut. Pernyataan ini sesuai dengan penelitian yang dilakukan oleh Widhiari \& Merkusiwati (2015) yang menjelaskan bahwa tingkat likuiditas yang dimiliki perusahaan berpengaruh negatif signifikan terhadap financial distress yang dialami perusahaan. Semakin besar hutang yang dimiliki perusahaan maka semakin besar kemungkinan perusahaan untuk mengalami kebangkrutan atau dengan kata lain leverage memiliki hubungan positif dengan memprediksi financial distress Fatmawati \& Rihardjo (2017) dan Amir \& Sudiyatno (2017).

H2a: Dampak pandemi terhadap prediksi kebangkrutan akan lebih kecil pada perusahaan yang sebelumnya memiliki posisi kas lebih kuat

$\mathbf{H}_{2 \mathbf{b}}$ : Dampak pandemi terhadap prediksi kebangkrutan akan lebih besar pada perusahaan yang sebelumnya memiliki rasio hutang lebih tinggi

\section{Metode Penelitian}

\section{Populasi \& Sampel}

Penelitian ini merupakan jenis penelitian kuantitatif. Perusahaan manufaktur yang terdaftar dalam Bursa Efek Indonesia (BEI) adalah populasi pada penelitian ini. Sampel untuk penelitian ini diambil dengan menggunakan metode purposive sampling dengan beberapa kriteria. Kriteria yang diterapkan untuk mengambil sampel pada penelitian ini antara lain (1) terdaftar dalam BEI di tahun 2020 (2) perusahaan memiliki informasi keuangan pada tahun 2019-2020 (3) perusahaan tersebut melaporkan keterbukaan informasi terkait dampak pandemi.

\section{Data \& Sumber Data}

Dampak pandemi COVID-19 menjadi variabel bebas pada penelitian ini. Tolak ukur dalam melihat seberapa besar dampak pandemi COVID-19 pada suatu perusahaan dapat dihitung menggunakan data keterbukaan informasi yang telah tersedia di Bursa Efek Indonesia (BEI). Keterbukaan informasi yang dilaporkan perusahaan terdampak COVID-19 menggambarkan apa saja dan seberapa besar pandemi COVID19 berpengaruh pada perusahaannya. Dampak pandemi COVID-19 pada masingmasing perusahaan diindentifikasi dan diperhitungkan menggunakan skor komposit untuk memperhitungkan indikator variabel dampak pandemi COVID-19. Skoring dampak pandemi COVID-19 terlampir pada Tabel 1.

Variabel terikat pada penelitian ini adalah prediksi kebangkrutan yang dihitung menggunakan analisis model Z-score dan kemudian diukur kembali menggunakan dummy score. Kebangkrutan suatu perusahaan dapat terlihat dari mulai memburuknya performa keuangan perusahaan. Thohari et al., (2015) menjelaskan bahwa analisis model Z-score dapat digunakan dalam menghitung prediksi kebangkrutan perusahaan dengan mengolah data keuangan perusahaan dan hasilnya dapat melihat kesehatan keuangan dari suatu perusahaan. Penelitian ini mengacu pada penelitian Tambunan et al., (2015) dengan menggunakan persamaan 
diskriminan sebagai berikut dalam metode analisis $Z$-score :

$Z=1,2 X_{1}+1,4 X_{2}+3,3 X_{3}+0,6 X_{4}+$ $1,0 X_{5}$

Keterangan :

$\boldsymbol{X}_{\mathbf{1}}=$ rasio modal kerja terhadap total aktiva

$\boldsymbol{X}_{\mathbf{2}}=$ rasio sisa laba ditahan terhadap total aktiva

$\boldsymbol{X}_{\mathbf{3}}=$ rasio laba sebelum bunga dan pajak

(EBIT) terhadap total aktiva

$\boldsymbol{X}_{\mathbf{4}}=$ rasio nilai pasar saham terhadap total hutang

$\boldsymbol{X}_{\mathbf{5}}=$ rasio penjualan terhadap total aktiva

Perusahaan terprediksi bangkrut apabila memiliki nilai Z-score kurang dari 1,81 dan mendapat dummy score sebesar 1 . Sedangkan dummy score sebesar 0 adalah untuk kategori grey area dan perusahaan terindikasi sehat dengan nilai Z-score $\geq$ 1,81. Variabel moderasi pada penelitian ini adalah kondisi keuangan perusahaan pra2020 yang dilihat dari kas ditangan tahun 2019 dan leverage tahun 2019.

Kas ditangan $=\frac{(\text { Kas \& Setara Kas })}{\text { Total Aset }}$

Leverage $=\frac{\text { Total Hutang }}{\text { Total Ekuitas }}$

\section{Teknik Analisis}

Penelitian ini menggunakan uji model analisis regresi logistik dengan model moderasi untuk menguji hipotesis yang telah dirumuskan. Regresi logistik dengan model moderasi dipilih karena pada penelitian ini terdapat variabel terikat yang diukur melalui skor dummy dan terdapat variabel moderasi. Pengujian Omnibus Test dilakukan terlebih dahulu sebelum melakukan uji hipotesis untuk memastikan bahwa model dinyatakan fit/layak diuji. Adapun uji hipotesis akan dilakukan melalui model analisis sebagai berikut:

Model $\mathrm{H}_{1}: Y=\beta_{0}+\beta_{1} X_{1}+e$

Model $\mathrm{H}_{2}: Y=\beta_{0}+\beta_{1} X_{1}+\beta_{2} X_{2}+$ $\beta_{3} X_{1} X_{2}+e$

Model $\mathrm{H}_{3}: Y=\beta_{0}+\beta_{1} X_{1}+\beta_{2} X_{3}+$ $\beta_{3} X_{1} X_{3}+e$
Keterangan :

$\begin{array}{ll}\mathbf{Y} & \text { : Prediksi Kebangkrutan } \\ \boldsymbol{X}_{\mathbf{1}} & \text { : Dampak Pandemi COVID-19 } \\ \boldsymbol{X}_{\mathbf{2}} & \text { : Kas Ditangan } \\ \boldsymbol{X}_{\mathbf{3}} & \text { : Leverage } \\ \boldsymbol{e} & \text { : Error }\end{array}$

\section{Hasil Penelitian dan Pembahasan}

\section{Objek Penelitian}

Populasi dalam penelitian ini adalah perusahaan manufaktur yang terdaftar di Bursa Efek Indonesia (BEI) tahun 2020. Berdasarkan kriteria yang telah ditentukan sebelumnya, sebanyak 13 perusahaan tidak dapat memenuhi kriteria (Tabel 1). Sehingga diperoleh 169 perusahaan yang menjadi objek penelitian.

Tabel 1

Populasi dan Sampel

\begin{tabular}{lcc}
\hline \multicolumn{2}{c}{ Keterangan } & Jumlah \\
\hline $\begin{array}{l}\text { Populasi perusahaan manufaktur yang } \\
\text { terdaftar tahun 2020 }\end{array}$ & 182 \\
$\begin{array}{l}\text { Eliminasi sampel karena tidak } \\
\text { mengungkapkan keterbukaan informasi }\end{array}$ & 3 \\
$\begin{array}{l}\text { Eliminasi sampel karena tidak tersedia } \\
\text { laporan keuangan }\end{array}$ & 9 \\
Eliminasi sampel karena data outlier & 1 \\
\hline Jumlah perusahaan sampel & 169 \\
\hline Sumber: Data penelitian (2020)
\end{tabular}

Analisis statistik deskriptif dalam penelitian ini terdiri dari nilai minimum, maksimum, rata-rata, serta standar devisiasi yang dijelaskan dalam Tabel 2.

Tabel 2 menunjukkan bahwa ratarata skor dampak COVID-19 hanya sebesar 7,63 dari total skor komposit 35. Hal ini menunjukkan bahwa dampak COVID-19 pada manufaktur di Indonesia tergolong relatif tidak fatal. Skor maksimal 35 akan diperoleh jika dampak COVID-19 sangat serius, seperti penghentian operasi total, pembatasan waktu operasional lebih dari 3 bulan, PHK terhadap mayoritas pegawai dan kondisi serius lainnya. Selain itu terdapat 42 perusahaan yang memiliki nilai minimum 0, yang artinya mereka sama sekali tidak terdampak COVID-19. 
Sebanyak 49\% (83 dari 169) perusahaan terprediksi bangkrut. Sejumlah 83 perusahan tersebut terdiri dari 40 perusahan sektor industri dasar dan kimia, 26 perusahaan industri aneka, dan 17 perusahan industri barang dan konsumsi. Rata-rata kas ditangan perusahaan pada akhir tahun 2019 adalah $8 \%$ dari total aset dan pada umumnya perusahaan memiliki saldo hutang 1,41 kali dari saldo ekuitasnya.

Tabel 2

Statistik Deskriptif

\begin{tabular}{lllll}
\hline \multicolumn{1}{c}{ Variabel } & Min & Maks & $\begin{array}{c}\text { Rata- } \\
\text { rata }\end{array}$ & $\begin{array}{c}\text { Standa } \\
\mathbf{r} \\
\text { Deviasi }\end{array}$ \\
\hline Dampak & 0 & 22 & 7,63 & 6,18 \\
Pandemi & & & & \\
Bangkrut & 0 & 1 & 0,49 & 0,50 \\
Kas & & 0,72 & 0,08 & 0,11 \\
& 0 & & & \\
Leverage & $-2,13$ & 23,92 & 1,41 & 2,84 \\
\hline
\end{tabular}

Sumber: Data penelitian (2020)

\section{Hasil Pengujian Statistik}

Tabel 3 berikut ini menunjukkan hasil pengujian kelayakan model penelitian ini.

Tabel 3

Hasil Uji Kelayakan Model

\begin{tabular}{lcll} 
& \multicolumn{3}{c}{ Hasil Uji Kelayakan Model } \\
\hline Model & Sign. Omnibus test & $\begin{array}{l}\text { Pseudo } \\
\text { Square }\end{array}$ & R \\
\hline 1 & 0,000 & $9,9 \%$ \\
2 & 0,000 & $24,8 \%$ \\
3 & 0,000 & $23,2 \%$ & \\
\hline *Sumber: data penelitian diolah (2020)
\end{tabular}

Tabel 3 menunjukkan perhitungan Signifikansi Omnibus Test yaitu sebesar 0,000 pada setiap model. Dengan demikian setiap model dinyatakan fit karena nilai signifikansi yang dihasilkan lebih kecil dari 0,05. Dari uji model 1 ditemukan bahwa nilai dari Pseudo $R$ Square menunjukkan nilai 9,9\%. Hal ini menunjukkan bahwa prediksi kebangkrutan yang dipengaruhi oleh dampak COVID-19 sebesar 9,9\%, lalu sebanyak $90,1 \%$ sisanya dipengaruhi oleh faktor lain. Uji model 2 menunjukkan nilai sebesar $24,8 \%$ pada pengujian Pseudo $R$ Square. Dengan demikian pada model 2 menunjukkan bahwa sebanyak 24,8\% prediksi kebangkrutan dipengaruhi oleh dampak pandemi COVID-19, kas di tangan serta interaksi keduanya dan sebanyak $75,2 \%$ lainnya dipengaruhi oleh faktorfaktor lainnya. Uji model 3 pada pengujian Pseudo R Square menunjukkan nilai $23,2 \%$. Dapat disimpulkan bahwa pada uji model 3 prediksi kebangkrutan oleh variabel bebas dinilai sebesar 23,2\% dan sebesar 76,8\% lainnya dipengaruhi oleh faktor diluar model penelitian ini.

Tabel 4

\begin{tabular}{|c|c|c|}
\hline & \multicolumn{2}{|c|}{$\begin{array}{c}\text { Tabel } 4 \\
\text { Hasil Uji Regresi }\end{array}$} \\
\hline & Koefisien & Signifikansi \\
\hline \multicolumn{3}{|l|}{ Model 1} \\
\hline COVID & 0,094 & $0,001 *$ \\
\hline \multicolumn{3}{|l|}{ Model 2} \\
\hline COVID & 0,073 & $0,044^{*}$ \\
\hline KAS & $-9,468$ & $0,017^{*}$ \\
\hline KAS*COVID & 0,084 & 0,845 \\
\hline \multicolumn{3}{|l|}{ Model 3} \\
\hline COVID & 0,039 & 0,351 \\
\hline LEV & 0,318 & 0,245 \\
\hline LEV*COVID & 0,041 & 0,215 \\
\hline
\end{tabular}

Hasil dari regresi diatas menunjukkan bahwa pada koefisian regresi model 1 (variabel dampak pandemi COVID-19) sebesar 0,094 dengan nilai signifikan sebesar 0,001 sehingga dapat disimpulkan bahwa dampak pandemi COVID-19 memiliki pengaruh positif terhadap prediksi kebangkrutan perusahaan. Dari hasil tersebut dapat diartikan bahwa semakin tinggi dampak pandemi COVID-19 yang diterima perusahaan semakin tinggi pula prediksi perusahaan tersebut akan mengalami kebangkrutan. Hasil pengujian regresi atas model 2 menunjukkan bahwa koefisien regresi pada variabel dampak pandemi COVID-19 sebesar 0,073 dengan nilai signifikan 0,044 , sedangkan koefisien regresi pada variabel kas ditangan sebesar 0,084 dengan nilai signifikan 0,845 . Hasil pengujian model 2 menunjukkan bahwa pada variabel dampak pandemi COVID-19 akan berpengaruh positif terhadap prediksi kebangkrutan. Adapun interaksi antara kas ditangan serta dampak pandemi COVID-19 tidak berpengaruh signifikan. Dengan 
demikian posisi kas pada tahun 2019 tidak mampu menjadi variabel moderasi pada model 2. Pada pengujian regresi model 3 diketahui bahwa baik variabel dampak pandemi COVID-19 maupun interaksinya dengan posisi hutang tidak memiliki pengaruh signifikan. Dengan begitu posisi hutang 2019 tidak mampu untuk menjadi variabel moderasi.

\section{Dampak Pandemi COVID-19 dan Prediksi Kebangkrutan}

Hipotesis pertama pada penelitian ini diterima dengan menyatakan bahwa dampak pandemi COVID-19 dapat menyebabkan suatu perusahaan mengalami bangkrut. Semakin besar dampak pandemi COVID-19 kepada suatu perusahaan maka akan semakin besar pula kemungkinan perusahaan tersebut untuk bangkrut. Hasil penelitian ini sesuai pada penelitian yang dilakukan oleh Syafrida et al., (2020) dan Hadiwardoyo (2020) yang menyatakan bahwa perusahaan yang tidak mampu bertahan dalam menghadapi dampak pandemi COVID-19 akan terancam mengalami pailit atau kebangkrutan. Perusahaan terdampak pandemi COVID-19 mengalami kerugian yang besar dan diiringi dengan adanya tuntutan dalam memenuhi kewajibannya baik untuk kegiatan operasional ataupun biaya untuk karyawan.

Moderasi Kondisi Keuangan Pra-2020 Pada Dampak Pandemi COVID-19 Terhadap Prediksi Kebangkrutan

Hipotesis kedua penelitian ini ditolak karena ditemukan bahwa kas pra-2020 (tahun 2019) tidak mampu memoderasi pengaruh dampak COVID-19 pada prediksi kebangkrutan perusahaan terdampak. Hasil uji hipotesis kedua penelitian ini didukung dengan penelitian yang dilakukan oleh Putri \& Merkusiwati (2014) dan Widarjo \& Setiawan (2009) yang menjelaskan bahwa likuiditas tidak berpengaruh signifikan pada financial distress. Seberapapun besar tingkat likuiditas yang dimiliki perusahaan tidak berpengaruh dalam memprediksi kemungkinan perusahaan untuk mengalami kebangkrutan. Kemungkinan hal ini disebabkan karena aspek pandemi ini sangat berdampak pada operasi perusahaan, bahkan pandemi masih terus berlangsung hingga saat ini (bulan Oktober 2020). Terganggunya aktivitas bisnis secara berkepanjangan dapat membuat perusahaan harus menanggung biaya tetap, yang kemungkinan tidak dapat terantisipasi oleh kas di tangan dalam kondisi luar biasa seperti ini.

Penelitian ini juga menemukan bahwa posisi hutang pra-2020 (tahun 2019) milik perusahaan tidak dapat memoderasi pengaruh dari dampak pandemi COVID-19 pada prediksi kebangkrutan yang akan dialami perusahaan karena adanya pandemi COVID-19. Hal tersebut menjelaskan bahwa perumusan hipotesis ketiga pada penelitian ini ditolak. Kemungkinannya adalah gangguan pandemi yang dirasakan dunia usaha sangat besar, sehingga kesulitan yang dialami perusahaan tidak hanya dari aspek kewajiban hutang saja. Berbagai hambatan dan usaha dialami secara bersama-sama, sehingga banyak aspek dapat berkontribusi pada prediksi kebangkrutan pada perusahaan terdampak. Hasil penelitian ini sama seperti penelitian yang dilakukan oleh Dewi et al., (2019) dan Srikalimah (2017) yang menyatakan bahwa besar kecilnya leverage yang dimiliki perusahaan tidak berpengaruh signifikan dalam memprediksi kemungkinan financial distress yang akan dialami perusahaan.

\section{Simpulan dan Saran}

\section{Simpulan}

Penelitian ini menemukan bahwa dampak pandemi COVID-19 membuat perusahaan menjadi terprediksi bangkrut. Namun demikian, kondisi keuangan pra-2020 (kas di tangan dan posisi hutang tahun 2019), tidak dapat memoderasi dampak pandemi terhadap prediksi kebangkrutan. Temuan bahwa posisi keuangan pra-2020 tidak mampu mengantisipasi dampak pandemi 
perlu disikapi manajemen untuk membuat strategi yang tidak hanya fokus pada kondisi kas maupun posisi hutang. Penelitian ini masih merupakan penelitian awal, sehingga menggunakan laporan keuangan kuartal 2 tahun 2020. Hal ini menyebabkan ada kemungkinan terdapat bias kualitas laporan keuangan karena belum diaudit.

\section{Saran}

Penelitian mendatang diharapkan dapat menggunakan laporan keuangan tahunan yang sudah diaudit untuk menghindari bias yang akan terjadi. Penelitian selanjutnya juga diharapkan untuk dapat meneliti strategi apa yang paling tepat dilakukan perusahaan untuk menghindari kebangkrutan akibat adanya pandemi COVID-19.

\section{Daftar Pustaka}

Almilia, L. S., \& Herdinigtyas, W. (2005). Analisis rasio camel terhadap prediksi kondisi bermasalah pada lembaga perbankan periode 2000-2002. Jurnal Akuntansi Dan Keuangan, 7(2), 131147.

https://doi.org/10.9744/jak.7.2.pp.131 $-147$

Amir, S., \& Sudiyatno, B. (2017). Pengaruh rasio keuangan untuk memprediksi probabilitas kebangkrutan pada perusahaan manufaktur yang terdaftar di Bursa Efek Indonesia. Dinamika Akuntansi, Keuangan Dan Perbankan, 2(1), 82-91. https://doi.org/1979-4878

Arfina, N. (2013). Analisis pengaruh likuiditas dan solvabilitas terhadap profitabilitas pada perusahaan makanan dan minuman yang terdaftar di BEI. Jurnal Fakultas Ekonomi, $1-23$.

Asia, V. E., \& Irwan. (2015). Pengaruh rasio keuangan terhadap prediksi kebangkrutan (Altman Z-Score) industri makanan dan minuman yang terdaftar di Bursa Efek Indonesia Tahun 2009-2011. Jurnal Visionida, 1(1), 47-59.

Badan Pusat Statistika. (2020). Analisis hasil survei dampak Covid-19 terhadap pelaku usaha. Badan Pusat Statistika.

https://www.bps.go.id/publication/20 20/09/15/9efe2fbda7d674c09ffd0978/ analisis-hasil-survei-dampak-covid19-terhadap-pelaku-usaha.htm

Burhanuddin, C. I., \& Abdi, M. N. (2020). Ancaman krisis ekonomi global dari dampak penyebaran virus corona (Covid-19). Jurusan Akuntansi, Universitas Muhammadiyah Makassar, 17, 710-718.

Bursa Efek Indonesia. (2020). Keterbukaan informasi.

https://www.idx.co.id/perusahaantercatat/keterbukaan-informasi/

Dewi, N. L. P. A., Endiana, I. D. M., \& Arizona, I. P. E. (2019). Pengaruh rasio likuiditas, rasio leverage dan rasio profitabilitas terhadap financial distress pada perusahaan manufaktur. Kumpulan Hasil Riset Mahasiswa Akuntansi (KHARISMA), 1(1), 322333.

Ding, W., Levine, R., Lin, C., \& XIe, W. (2020). Corporate immunity to the Covid-19 pandemic. Working Paper 27055 , http://www.nber.org/papers/w27055. https://doi.org/10.1017/CBO9781107 415324.004

Fatmawati, V., \& Rihardjo, I. B. (2017). Pengaruh likuiditas, leverage, aktivitas dan profitabilitas dalam memprediksi financial distress. Ilmu dan Riset Akuntansi, 6(10).

Hadiwardoyo, W. (2020). Kerugian ekonomi nasional akibat pandemi Covid-19. Journal of Business and Entrepreneurship, 2(2), 83-92. https://doi.org/10.24853/baskara.2.2.8 3-92

Nurmasari, I. (2020). Dampak Covid - 19 
terhadap perubahan harga saham dan volume transaksi. Jurnal Sekuritas (Saham, Ekonomi, Keuangan Dan Investasi ), 3(1), 230-236.

Pangkey, P. C., Saerang, I. S., \& Maramis, J. B. (2018). Analisis prediksi kebangkrutan dengan menggunakan metode altman dan metode zmijewski pada perusahaan bangkrut yang pernah go public di Bursa Efek Indonesia. Jurnal EMBA: Jurnal Riset Ekonomi, Manajemen, Bisnis Dan Akuntansi, 6(4), 3178-3187. https://doi.org/10.35794/emba.v6i4.2 1292

Putri, N. W. K. A., \& Merkusiwati, N. A. K. L. (2014). Pengaruh mekanisme corporate governance, likuiditas, leverage, dan ukuran perusahaan pada financial distress. E-Jurnal Akuntansi, 7(1), 93-106.

Putri, R. K., Sari, R. I., Wahyuningsih, R., \& Meikhati, E. (2020). Efek pandemi Covid-19: dampak lonjakan angka PHK terhadap penurunan perekonomian di Indonesia. Jurnal Bismak, 1(1), 50-55.

Qin, X., Huang, G., Shen, H., \& Fu, M. (2020). Covid-19 pandemic and firmlevel cash holding-moderating effect of goodwill and goodwill impairment. Emerging Markets Finance and Trade, 56(10), 22432258.

https://doi.org/10.1080/1540496X.20 20.1785864

Ramadhani, A. S., \& Lukviarman, N. (2009). Perbandingan analisis prediksi kebangkrutan menggunakan model altman pertama, altman revisi, dan altman modifikasi dengan ukuran dan umur perusahaan sebagai variabel penjelas (studi pada perusahaan manufaktur yang terdaftar di Bursa Efek Indonesia). Jurnal Siasat Bisnis, 13(1), $15-28$. https://doi.org/10.20885/jsb.vol13.iss 1.art2

Rompas, G. P. (2013). Likuiditas, solvabilitas dan rentabilitas terhadap nilai perusahaan BUMN yang terdaftar di BEI. Jurnal EMBA, 1(3), 252-262.

Selasi, D. (2020). Dampak pandemic disease terhadap perkembangan pasar modal syariah di Indonesia. Jurnal Ilmiah Indonesia, 5(5), 1-13.

Silalahi, Dina Eva Santi, \& Ginting, Rasinta Ria. (2020). Strategi kebijakan fiskal pemerintah Indonesia dalam menghadapi dampak pandemi Covid-19. Jurnal Ekonomi \& Ekonomi Syariah, 3(2), 156-167.

Srikalimah. (2017). Pengaruh profitabilitas, likuiditas dan leverage dalam memprediksi financial distress (Studi empiris pada perusahaan yang terdaftar di BEI periode 2009-2013). Jurnal Akuntansi \& Ekonomi FE. UN PGRI Kediri, 2(1), 43-66.

Syafrida, Safrizal, \& Suryani, R. (2020). Pemutusan hubungan kerja masa pandemi Covid-19 perusahaan terancam dapat dipailitkan. Pamulang Law Review, 3(1), 19-30. http://www.openjournal.unpam.ac.id/i ndex.php/palrev/article/view/6532

Tambunan, R. W., Dwiatmanto, \& N.P, M. . W. E. (2015). Analisis prediksi kebangkrutan perusahaan dengan menggunakan metode altman (zscore) (studi pada subsektor rokok yang listing dan perusahaan delisting di Bursa Efek Indonesia tahun 2009 2013). Jurnal Administrasi Bisnis, 19(1), 2-11.

Thohari, M. Z., Sudjana, N., \& A, Zahroh Z. (2015). Prediksi kebangkrutan menggunakan analisis model Z-score ( studi pada subsektor textile mill products yang terdaftar di Bursa Efek Indonesia periode 2009-2013 ). Jurnal Administrasi Bisnis, 28((1)), 149-157.

http://administrasibisnis.studentjourna 1.ub.ac.id/index.php/jab/article/view/1 140

Widarjo, W., \& Setiawan, D. (2009). 
Pengaruh rasio keuangan terhadap kondisi financial distress perusahaan otomotif. Jurnal Bisnis Dan Akuntansi, 11(2), 107-119.

Widhiari, N. L. M. A., \& Merkusiwati, N. K. L. A. (2015). Pengaruh rasio likuiditas, leverage, operating capacity, dan sales growth terhadap financial distress. E-Jurnal Akuntansi, 11(2), 456-469.

Yami, N. R. H., \& Pratiwi, R. D. (2015). Prediksi kebangkrutan dengan menggunakan metode altman $\mathrm{z}$ score, springate dan zmijewski pada perusahaan property dan real estate yang terdaftar di BEI Tahun 20112013. Jurnal Akuntansi. Fakultas Ekonomi Dan Bisnis. Universitas Dian Nuswantoro Semarang., 1-20.

\section{Lampiran}

Tabel 5

Skor Indikator Keterbukaan Informasi

\begin{tabular}{|c|c|c|}
\hline INDIKATOR & URAIAN & SKOR \\
\hline \multirow{4}{*}{$\begin{array}{l}\text { Pengaruh COVID-19 terhadap } \\
\text { Kondisi Kelangsungan Usaha }\end{array}$} & Operasional terganggu pandemi COVID-19 & $0-1$ \\
\hline & $\begin{array}{l}\text { Terdapat pembatasan dan/atau penghentian } \\
\text { operasional }\end{array}$ & $0-3$ \\
\hline & Jangka waktu pembatasan operasional & $0-3$ \\
\hline & $\begin{array}{l}\text { Kontribusi pendapatan yang hilang karena } \\
\text { pandemi COVID-19 }\end{array}$ & $0-4$ \\
\hline \multirow{3}{*}{$\begin{array}{l}\text { Pengaruh COVID-19 terhadap } \\
\text { Tenaga Kerja Perusahaan }\end{array}$} & Tenaga kerja PHK & $0-2$ \\
\hline & Tenagar kerja dirumahkan & $0-2$ \\
\hline & $\begin{array}{l}\text { Tenaga kerja terdampak situasi lainnya (sepeti } \\
\text { pemotongan gaji) }\end{array}$ & $0-2$ \\
\hline \multirow{2}{*}{$\begin{array}{l}\text { Pengaruh COVID-19 } \\
\text { Pendapatan Perusahaan }\end{array}$} & Penurunan total pendapatan & $0-4$ \\
\hline & Penurunan laba bersih & $0-4$ \\
\hline \multirow{3}{*}{$\begin{array}{l}\text { Pengaruh COVID-19 } \text { terhadap } \\
\text { Pemenuhan Kewajiban Keuangan } \\
\text { Jangka Pendek }\end{array}$} & Pemenuhan kewajiban pokok & $0-1$ \\
\hline & Pemenuhan utang bunga kewajiban pokok & $0-1$ \\
\hline & Jumlah kewajiban dan bunga jangka pendek & $0-4$ \\
\hline \multirow{4}{*}{$\begin{array}{l}\text { Pengaruh COVID-19 terhadap } \\
\text { Permasalahan Hukum }\end{array}$} & Gugatan pailit & $0-1$ \\
\hline & Pembatalan kontrak material & $0-1$ \\
\hline & Somasi/wanprestasi & $0-1$ \\
\hline & Lainnya & $0-1$ \\
\hline & Total Skor Maksimum & 35 \\
\hline
\end{tabular}

